\title{
Changes in Blood Gas Tensions Following Administration of Amine Buffer THAM to Infants with Respiratory Distress Syndrome
}

\author{
J. M. GUPTA ${ }^{\star}$, G. W. DAHLENBURG†, and J. A. DAVIS \\ From the Nuffield Neonatal Research Unit, Institute of Child Health, Hammersmith Hospital, \\ Du Cane Road, London W.12
}

A number of workers have shown that the prognosis in respiratory distress syndrome (RDS) is more closely related to the arterial oxygen tension than to acid-base disturbance, and depends to a large extent on the degree of shunting of venous blood past the gas-exchanging portions of lung, i.e. on the extent to which the arterial $\mathrm{Po}_{2}$ responds to an increase in the concentration of oxygen breathed (Boston, Geller, and Smith, 1966; Gupta, 1966; Moss, Emmanouilides, Retorri, Higashino, and Adams, 1965). These findings are to some extent in conflict with claims that the prognosis is improved by correction of the secondary acid-base disturbance by infusion of glucose/bicarbonate solutions (Usher, 1959; Hutchison, Kerr, Douglas, Inall, and Crosbie, 1964). It occurred to us that these two points of view might be reconciled if it could be shown that correction of $p \mathrm{H}$ leads to improvement in oxygenation and diminution of shunting, a consequence that might be predicted in the newborn from the dependence of pulmonary perfusion on $p \mathrm{H}$ and blood gas tensions (Cassin, Dawes, Mott, Ross, and Strang, 1964) as well as on adequate cardiac function. THAM rather than bicarbonate was used because of its greater alkalinity and its ability to lower the $\mathrm{P}_{\mathrm{a}} \mathrm{CO}_{2}$ (Nahas, 1959; Holmdahl, Nahas, Hassam, and Verosky, 1961) as well as to raise the $p \mathrm{H}$. It was decided to measure $\mathrm{Po}_{2}$ levels in arterial blood before and after administration of THAM and to see whether any improvement in $\mathrm{P}_{\mathrm{a}} \mathrm{O}_{2}$ so achieved would be sustained. During the course of the study the work of Chu, Clements, Cotton, Klaus, Sweet, Thomas, and Tooley (1965) in Singapore became known to us, and reinforced our belief that pulmonary hypoperfusion might be a

Received January 3, 1967.

* Percy J. Neate Research Fellow (Clothworkers' Company).

† Supported by the Frank J. Duval Travelling Fellowship (Melbourne). major or reversible factor in the pathogenesis of RDS. The results reported below do, in our opinion, bear out this view.

\section{Materials and Methods}

The subjects of this investigation were newborn infants admitted to the neonatal ward of the Hammersmith Hospital. Most of the infants were born in the hospital but a few were admitted from the district or from other hospitals. The infants born at Hammersmith Hospital were assessed at one minute using a modification of the Apgar method (Tizard, 1964).

All infants were nursed in incubators. The incubator temperature varied between $32^{\circ}$ and $35^{\circ} \mathrm{C}$. but was kept constant for a given baby at a level as close as possible to the neutral temperature zone appropriate to its birthweight (Scopes and Ahmed, 1966). At the time the study was made it was the rule to maintain the humidity at nearly $100 \%$. The infants were kept under constant observation by trained nurses during the period of investigation. The observations consisted of $1 / 4$-hourly respirations, 1/2-hourly apex beat, hourly rectal temperature, and general comments on the condition of the baby, i.e. skin colour, muscle tone, response to stimuli, irritability, and character of respiration. The first feed (usually at 6 hours) consisted of water. This was followed by full-strength expressed breast milk $20 \mathrm{ml}$. $/ \mathrm{kg}$. divided into 8 feeds, with a daily increment of $20 \mathrm{ml}$. $/ \mathrm{kg}$., so that at 8 days the infants were receiving $160 \mathrm{ml} . / \mathrm{kg}$. per day. This regimen was well tolerated.

A clinical diagnosis of RDS was made if two of the following three criteria were fulfilled on assessment at the age of 4 hours: (1) a respiratory rate of 60 or more on two successive observations, or a rise in respiratory rate of more than 20 breaths per minute from 1 to 4 hours of age; (2) intercostal or subcostal recession; and (3) grunting on expiration.

An $x$-ray film of the chest was obtained as early as possible and frequent clinical assessment was carried out to confirm the diagnosis and to distinguish RDS from other causes of dyspnoea, such as intrapartum pneumonia, requiring specific therapy. All babies who died had a necropsy. 
Arterial blood samples were collected from the iliac artery or the abdominal aorta by means of a polyvinyl catheter, size French 5 (Pharmaseal K32 premature infant feeding tube) inserted into an umbilical artery. The catheter was securely stitched to the umbilical stump and the open end was closed with a rubber bung. The cord stump and the surrounding skin were sprayed with 'polybactrin' solution and covered with a sterile dressing.

Umbilical arterial blood samples of 0.4-0.6 ml. were taken under anaerobic conditions with a 2 or $5 \mathrm{ml}$. paraffin-lubricated glass syringe, the dead space of which had been filled with heparin (1000 units $/ \mathrm{ml}$.). The syringe was then sealed with a metal cap. Most measurements of arterial oxygen tensions $\left(\mathrm{P}_{\mathrm{a}} \mathrm{O}_{2}\right)$ and $p \mathrm{H}$ were made immediately, the laboratory being adjacent to the neonatal ward. They were not routinely made in duplicate, as this would have involved taking unduly large samples. $\mathbf{P}_{\mathrm{a}} \mathrm{CO}_{2}$ and standard bicarbonate were determined within 1 hour. It was aimed to take blood samples at 3-hourly intervals for the first 12 hours and 6-hourly intervals thereafter until the catheter was removed, but in practice it was found necessary to sample more frequently in severely ill babies and the above régime was not strictly adhered to for a number of practical reasons. After taking the blood sample the catheter was filled with heparinized saline solution (10 units $/ \mathrm{ml}$.) to prevent clotting.

Before collection of a blood sample the baby's rectal temperature was taken with a clinical thermometer (inserted 3-4 cm.) and the oxygen concentration in the incubator was measured with a Beckman D2 oxygen analyser. $\mathrm{P}_{\mathrm{a}} \mathrm{O}_{2}$ measurements were carried out with a Beckman $\mathrm{O}_{2}$ macro-electrode which was calibrated by using gas mixtures containing known concentrations of oxygen. Cord blood was equilibrated with the same gas mixtures in a tonometer and the $\mathrm{Po}_{2}$ was measured after equilibration. The average difference in $\mathrm{Po}_{2}$ between gas and blood equilibrated with the same gas was determined and a correction factor was applied (this was less than $3 \%$ ). The gas mixtures were analysed by the Lloyd-Haldane technique. All the $\mathrm{P}_{\mathrm{a}} \mathrm{O}_{2}$ values measured, except those above $200 \mathrm{~mm}$. $\mathrm{Hg}$ were converted by using a nomogram (Bradley, Stupfel, and Severinghaus, 1956) to patient's rectal temperature. For $\mathrm{P}_{\mathrm{a}} \mathrm{O}_{2}$ values above $200 \mathrm{~mm}$. $\mathrm{Hg}$ the temperature corrections recommended by Hedley-Whyte and Laver (1964) have been used.

Arterial blood $p \mathrm{H}$ was measured at $37^{\circ} \mathrm{C}$. with a direct reading $p \mathrm{H}$ meter (Electronic Instruments Ltd.) correcting for temperature by adding or subtracting 0.0147 for each degree centigrade by which the body temperature differed from $37^{\circ} \mathrm{C}$. (Rosenthal, 1948). By measuring the change in corrected $p \mathrm{H}$ after the sample had been equilibrated (using a home-made apparatus, Stevens and Lanning, 1964) with $3.5 \%$ and $6.5 \% \mathrm{CO}_{2}$ in oxygen, $\mathrm{P}_{\mathrm{a}} \mathrm{CO}_{2}$ was derived by means of interpolation (Peters, 1923; Astrup, 1956). No significant difference was observed between the calculated $\mathrm{P}_{\mathrm{a}} \mathrm{CO}_{2}$ values and direct simultaneous measurements made with a $\mathrm{CO}_{2}$ electrode.
THAM was administered as a $3 \cdot 6 \%$ solution $(0 \cdot 3 \mathrm{M})$, the $p \mathrm{H}$ of which had been adjusted to approximately $8 \cdot 8$ at $37^{\circ} \mathrm{C}$. by admixture with its hydrochloride. Dosage was empirical, the initial dose based on initial $p \mathrm{H}$ and birthweight amounting to approximately $1 \mathrm{ml}$. $/ \mathrm{kg}$. for each $p \mathrm{H}$ unit below 7.4. Further doses were given according to the changes in $\mathrm{P}_{\mathrm{a}} \mathrm{O}_{2}, \mathrm{pH}$, and $\mathrm{PcO}_{2}$ achieved. The properties of THAM and the progressive nature of the illness are such that it was decided not to base the dosage on the apparent base deficit; however, THAM was not given unless arterial $\mathrm{PCO}_{2}$ was above $40 \mathrm{~mm}$., $p \mathrm{H}$ lower than $7 \cdot 25$, and $\mathrm{P}_{\mathrm{a}} \mathrm{O}_{2}$ indicated a considerable shunt.

Early in the study THAM was given either by the umbilical artery or vein, but in the latter stages entirely by the umbilical vein because of apparently more beneficial results. The rate of injection was approximately $1 \mathrm{ml} . / \mathrm{min}$., and every dose was followed by a 'chaser' of saline to clear the dead space. Blood samples were taken immediately before giving THAM and again shortly afterwards, the average interval being 12 minutes (range 4-30 minutes). Careful histological examination in those babies who subsequently died failed to show any macro- or microscopic evidence of damage to vessel walls (whether artery or vein) or to the tissues supplied by them (such as the liver in the case of the umbilical vein, or the leg muscles in the case of the artery).

Surface activity of lung extracts was measured with a Wilhelmy balance, in two cases supplemented by static pressure volume curves.

Blood pressure measurements were made using the Minogograph 42B electromanometer. The transducer was connected to the catheter in the umbilical artery after previously being standardized with a mercury manometer.

Determination of arterial $\mathbf{P o}_{2}$ at alveolar $\mathbf{P o}_{2}$ $660 \mathrm{~mm}$. $\mathrm{Hg}$ (i.e. breathing $100 \%$ oxygen with alveolar $\mathrm{Pco}_{2} 40 \mathrm{~mm}$. $\mathrm{Hg}$ ). The shunt equation can be used to calculate the relation between alveolar $\mathrm{Po}_{2}\left(\mathbf{P}_{\mathbf{A}} \mathrm{O}_{2}\right)$ and arterial $\mathrm{Po}_{2}\left(\mathrm{P}_{\mathrm{a}} \mathrm{O}_{2}\right)$ (Nelson and Reynolds, 1964). Assuming the arteriovenous oxygen difference to be $4 \mathrm{ml} . / 100 \mathrm{ml}$., and oxygen capacity of $\mathrm{Hb}$ to be $20 \mathrm{ml}$. $\mathrm{O}_{2}$ per $100 \mathrm{ml}$. blood, isopleths (shunt lines) were constructed (Fig. 1) by calculating the $\mathrm{P}_{\mathrm{a}} \mathrm{O}_{2}$ for any given $\mathrm{P}_{\mathrm{A}} \mathrm{O}_{2}$ at various degrees of shunting. If the calculations are made by assuming any other arteriovenous oxygen difference or any other oxygen capacity of the $\mathrm{Hb}$ or both, the isopleths retain the same shape but shift in position. It follows that if the $\mathrm{P}_{\mathrm{a}} \mathrm{O}_{2}$ is measured at a known $\mathrm{P}_{\mathrm{A}} \mathrm{O}_{2}$ (assuming $\mathrm{P}_{\mathrm{A}} \mathrm{CO}_{2}=40 \mathrm{~mm}$.) one can derive from the isopleths (irrespective of the oxygen capacity of the blood or the arteriovenous oxygen difference) the expected $\mathrm{P}_{\mathrm{a}} \mathrm{O}_{2}$, were the infant to be breathing $100 \%$ oxygen (i.e. at $\mathrm{P}_{A} \mathrm{O}_{2} 660 \mathrm{~mm}$. $\mathrm{Hg}$ where $\mathrm{P}_{\mathrm{A}} \mathrm{CO}_{2}$ is assumed to be $40 \mathrm{~mm}$. $\mathrm{Hg}$ ). This provides a useful means for comparison in babies breathing different concentrations of oxygen, but it should be emphasized that the values so obtained usually differ from the actual $\mathrm{P}_{\mathrm{a}} \mathrm{O}_{2}$ when breathing $100 \%$ oxygen and are, therefore, of purely illustrative value. This could be because increased oxygen concentrations in the alveoli may in themselves decrease 


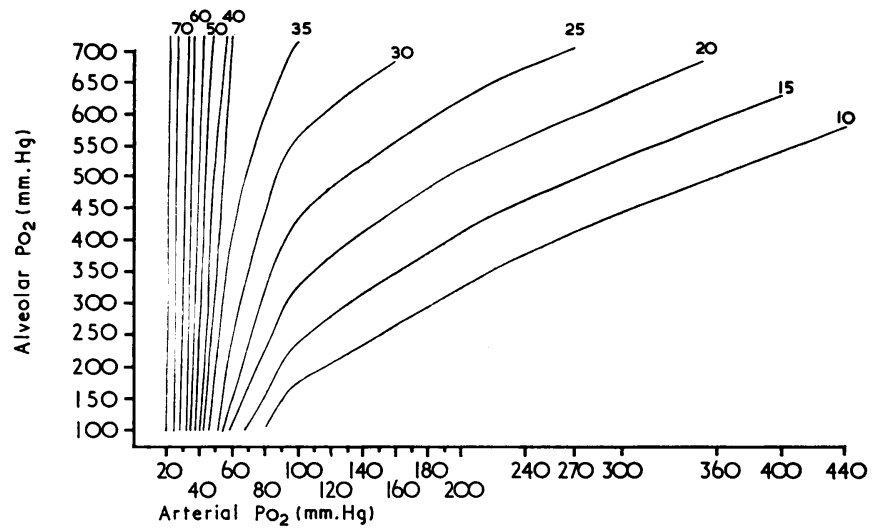

FIG. 1.-Isopleths (shunt lines) showing relation between alveolar and arterial oxygen tension (for derivation, see text). The numbers refer to percentage shunts.

shunting. The actual $\mathrm{P}_{\mathrm{a}} \mathrm{CO}_{2}$ was of course taken into account when placing a particular reading on the appropriate isopleth, and therefore the apparent diminution of shunting after THAM could not have been caused by the moderate fall in $\mathrm{P}_{\mathrm{a}} \mathrm{CO}_{2}$ produced by the drug. For comparative purposes $\mathrm{P}_{\mathrm{A}} \mathrm{O}_{2}$ values reported in this paper are derived values for $\mathrm{P}_{\mathrm{A}} \mathrm{O}_{2} 660 \mathrm{~mm}$. $\mathrm{Hg}$.

\section{Results}

We have grouped the infants into 'good prognosis cases' and 'bad prognosis cases' in line with the findings of Boston et al., and Moss et al. (1965), who have noted that nearly all deaths due to RDS alone are in babies whose $\mathrm{P}_{\mathrm{a}} \mathrm{O}_{2}$ cannot be raised above $100 \mathrm{~mm}$. $\mathrm{Hg}$ in $100 \%$ oxygen between 3 and 6 hours after birth. From Table I it can be seen that the deaths in the group where this degree of oxygenation was achieved were not due directly to respiratory distress.

Infants with 'good prognosis' RDS. There were 33 infants in this group; 23 survived, 10 died.

(a) Surviving infants of 'good prognosis' RDS group. None of these was given any alkali or buffer (THAM or bicarbonate), despite the fact that in all but two infants the $p \mathrm{H}$ was less than 7.30 and in three infants was less than $7 \cdot 20$ when first measured. In all cases the $p \mathrm{H}$ rose spontaneously as the infant achieved a satisfactory arterial oxygen tension.

All these infants were given added oxygen, the concentration of which was adjusted according to

TABLE I

'Good Prognosis' Respiratory Distress

\begin{tabular}{|c|c|c|c|c|c|c|}
\hline \multirow{2}{*}{$\begin{array}{c}\text { Infant } \\
\text { No. }\end{array}$} & \multirow{2}{*}{$\begin{array}{c}\text { Gesta- } \\
\text { tional } \\
\text { Age } \\
\text { (wk.) }\end{array}$} & \multirow{2}{*}{$\begin{array}{l}\text { Birth- } \\
\text { weight } \\
\text { (g.) }\end{array}$} & \multirow{2}{*}{$\begin{array}{l}\text { Associated } \\
\text { Conditions }\end{array}$} & \multicolumn{2}{|c|}{ Post-mortem Findings } & \multirow{2}{*}{ Comment } \\
\hline & & & & $\begin{array}{l}\text { Immediate Cause } \\
\text { of Death }\end{array}$ & State of Lungs & \\
\hline 24 & 25 & 820 & - & Intraventricular & Atelectasis & Satisfactory blood gas tensions \\
\hline 25 & 29 & 1680 & Hydrops (Rh.) & $\begin{array}{l}\text { haemorrhage } \\
\text { Respiratory failure; } \\
\text { cardiac failure }\end{array}$ & $\begin{array}{l}\text { Hyaline } \\
\text { membranes }\end{array}$ & $\begin{array}{l}\text { Twin pregnancy; twin I } \\
\text { stillborn }\end{array}$ \\
\hline 26 & 30 & 1560 & Apnoeic attacks & Massive pulmonary & Atelectasis & $\begin{array}{l}\text { Satisfactory blood gas tensions } \\
\text { until apnoeic attacks at } 14 \mathrm{hr} \text {. }\end{array}$ \\
\hline 27 & 32 & 1240 & Apnoeic attacks & $\begin{array}{l}\text { Intraventricular } \\
\text { haemorrhage }\end{array}$ & Atelectasis & Satisfactory blood gas tensions \\
\hline 28 & 32 & 1240 & Apnoeic attacks & Intraventricular & Atelectasis & Satisfactory blood gas tensions \\
\hline 29 & 33 & 1840 & Severe Rhesus & $\begin{array}{r}\text { haemorrhage } \\
\text { Hypoglycaemia }\end{array}$ & Hyaline & Satisfactory blood gas tensions \\
\hline 30 & 34 & 1460 & & $\begin{array}{l}\text { Intraventricular } \\
\text { haemorrhage }\end{array}$ & & Satisfactory blood gas tensions \\
\hline 31 & 36 & 2070 & 一 & $\begin{array}{c}\text { Intraventricular } \\
\text { haemorrhage }\end{array}$ & $\begin{array}{l}\text { Hyaline } \\
\text { membranes }\end{array}$ & Satisfactory blood gas tensions \\
\hline 32 & 37 & 2380 & $\begin{array}{l}\text { Intrapartum } \\
\text { asphyxia (cord } \\
\text { round neck) }\end{array}$ & $\begin{array}{l}\text { Cerebral birth } \\
\text { injury }\end{array}$ & Atelectasis & $\begin{array}{l}\text { Maintained with IPPR from } \\
\text { age of } 4 \text { hours; repeated } \\
\text { fits }\end{array}$ \\
\hline 33 & 37 & 2650 & Maternal diabetes & Air embolism & $\begin{array}{l}\text { Hyaline } \\
\text { membranes }\end{array}$ & $\begin{array}{l}\text { Satisfactory blood gas tensions; } \\
\text { air embolism when umbilical } \\
\text { venous catheter open }\end{array}$ \\
\hline
\end{tabular}


arterial oxygen tensions. The initial $\mathrm{P}_{\mathrm{a}} \mathrm{CO}_{2}$ values were (with one exception) above the mean for normal infants of birthweight less than $2500 \mathrm{~g}$. (unpublished data).

(b) Fatal case of 'good prognosis' RDS group. The immediate cause of death and the lung findings at necropsy are shown in Table I. Nos. 25 and 32 were the only infants not to maintain satisfactory arterial oxygen tensions in the course of their illness. The remainder, who were recovering from respiratory distress, as judged by the ability to maintain satisfactory arterial oxygen tensions with decreasing ambient oxygen requirements, died as the result of secondary factors, as shown in the Table.

THAM was given to infants $24,25,26$, and 32 in the terminal stages of their illness. There was a transient, but unsustained, rise in the $\mathrm{P}_{\mathrm{a}} \mathrm{O}_{2}$ and $p \mathrm{H}$. Infant No. 29 was given THAM when his condition deteriorated following an exchange transfusion at the age of 1 hour; satisfactory $\mathrm{P}_{\mathrm{a}} \mathrm{O}_{2}$ was maintained from 8 to 22 hours when he suddenly collapsed and died. A blood sample taken at this time showed a glucose level of less than $10 \mathrm{mg} . / 100 \mathrm{ml}$.

In 4 of those infants dying of intraventricular haemorrhage THAM was not given at any stage; in 1 it was given terminally (infant No. 24).

Infants with 'bad prognosis' RDS. There were 25 infants in this group; 10 survived, 15 died. Table II shows the relevant details. The age at which the initial data were obtained was not 3 hours in all cases, for as experience was gained in the use of THAM, infants were treated as early as possible in the illness; moreover, at the beginning of the study THAM was given only if the $p \mathrm{H}$ fell below $7 \cdot 10$, but later it was given when the $\mathrm{P}_{\mathrm{a}} \mathrm{O}_{2}$ was less than $100 \mathrm{~mm} . \mathrm{Hg}$ in $100 \%$ oxygen, when the $p \mathrm{H}$ was less than $7 \cdot 20$, or when the $\mathrm{P}_{\mathrm{a}} \mathrm{CO}_{2}$ was greater than 45 . The initial dose of THAM, the total of subsequent doses, and the gas tensions and $p \mathrm{H}$ before and after THAM are also shown.

In a high proportion of these infants there was a rapid and substantial rise in the $\mathrm{P}_{\mathrm{a}} \mathrm{O}_{2}$ following THAM. Fig. 2 shows this response. All values in this and subsequent figures show the calculated $\mathrm{P}_{\mathrm{a}} \mathrm{O}_{2}$ (derived from isopleths) for an alveolar oxygen tension of $660 \mathrm{~mm}$. Hg. (It should be pointed out that as the arterial oxygen tensions rose following THAM the ambient oxygen was lowered.)

When THAM was given in the first 8 hours of the illness any rise in arterial oxygen tension that was obtained was usually sustained. This effect was much more obvious when THAM was given via the umbilical vein, and was associated with dramatic clinical improvement in infant No. 52 and with less

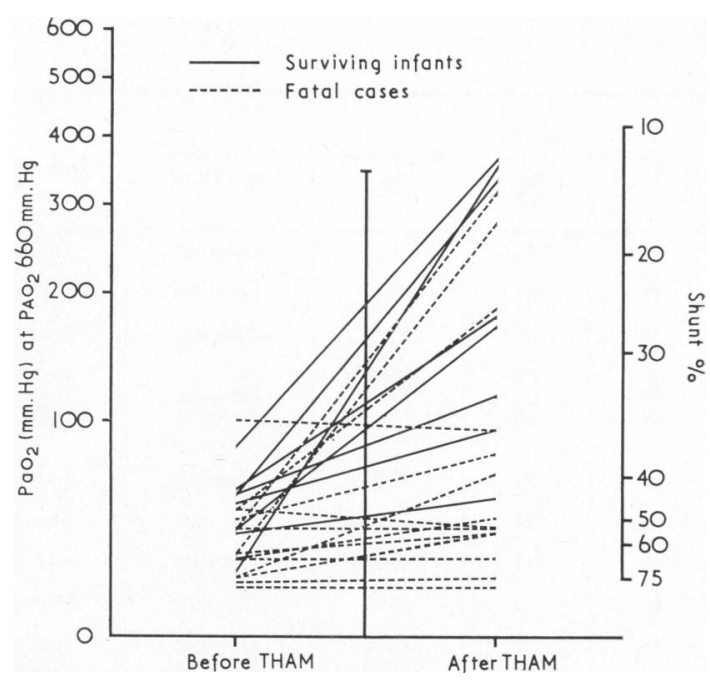

FIG. 2.-Severe RDS. Arterial oxygen tension before and after giving THAM in 22 cases. The percentage shunts are shown (see text).

dramatic but still substantial improvement in Nos. 37,44 , and 45.

There was no response to the initial dose of THAM in one infant (No. 45), but a substantial and sustained rise in the $\mathrm{P}_{\mathrm{A}} \mathrm{O}_{2}$ followed a second dose.

The $p \mathrm{H}$ in all these infants rose following THAM and again this rise was sustained in 8 out of the 10 . In one of the other two (No. 44) bicarbonate (10 mEq) was given at the age of $6 \frac{1}{2}$ hours, with improvement in the $p \mathrm{H}$. In the other infant who failed to respond to THAM or bicarbonate, it was apparent at 20 hours that there was a superimposed pneumonia.

The $\mathrm{P}_{\mathrm{a}} \mathrm{CO}_{2}$, which was high in 9 of the 10 cases, fell following THAM in 8 of them (in one after the second dose). Cases 52 and 44 illustrate these points.

Case 52. This infant was born by the breech following a spontaneous labour. The baby was apnoeic at 1 minute of age, with a heart rate of $96 / \mathrm{min}$., and was limp and blue. He was intubated and given intermittent positive pressure respiration (IPPR) and began breathing shortly afterwards. At 2 hours of age he was still limp, was very cyanosed in $30 \%$ oxygen, and had a respiratory rate of $60 / \mathrm{min}$., with marked expiratory grunting and severe costal recession. The air entry by auscultation was negligible. Chest $x$-ray film was compatible with RDS. The relevant gas tensions and $p H$ changes are shown in Fig. 3. There was a sudden and dramatic improvement in the infant's condition during the intravenous injection of THAM : he became pink, cried, moved all his limbs, and lost his costal recession. This 


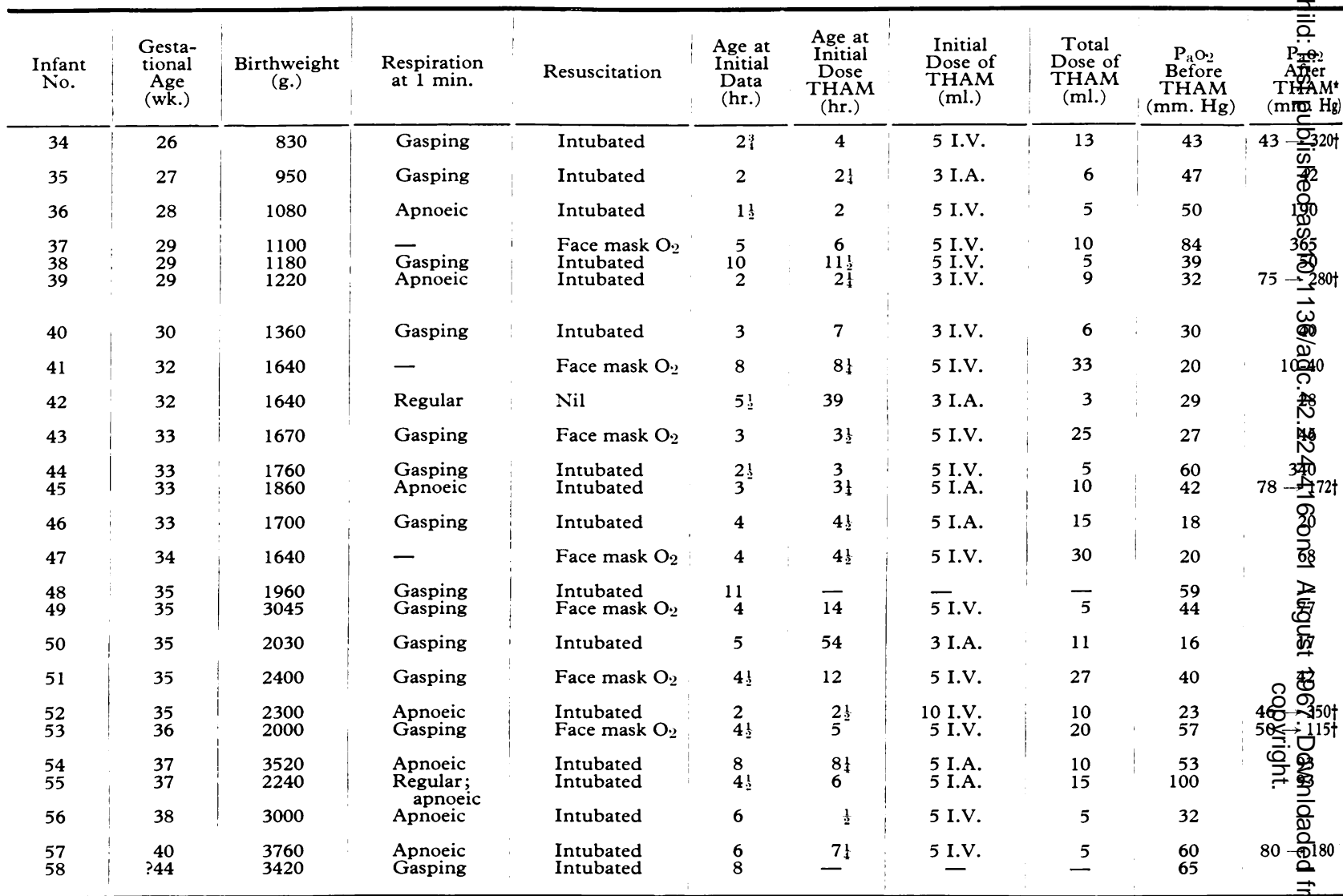

* Average time after THAM $=12$ minutes. + Response to further doses of THAM. IVH = intraventricular haemorrhage.

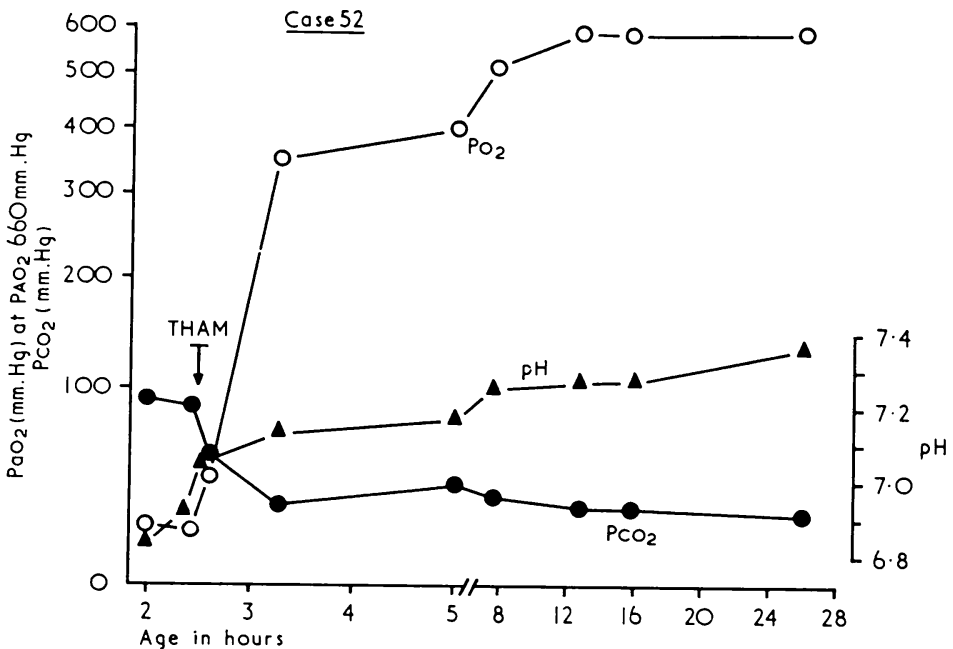

FIG. 3.-Case 52. Arterial oxygen tension, $\mathrm{pH}$, and $\mathrm{P}_{\mathrm{Co.}}$ before and after THAM (see text). 


\begin{tabular}{|c|c|c|c|c|c|c|c|}
\hline \multirow{2}{*}{$\begin{array}{c}p \mathrm{H} \\
\text { Before } \\
\text { THAM }\end{array}$} & \multirow{2}{*}{$\begin{array}{c}p \mathrm{H} \\
\text { After } \\
\text { THAM }\end{array}$} & \multirow{2}{*}{$\begin{array}{c}\text { PaCO.2 }_{2} \\
\text { Before } \\
\text { THAM } \\
(\mathrm{mm} . \mathrm{Hg})\end{array}$} & \multirow{2}{*}{$\begin{array}{c}\mathrm{PaCO}_{\mathrm{a}} \\
\text { After } \\
\text { THAM } \\
(\mathrm{mm} . \mathrm{Hg})\end{array}$} & \multirow{2}{*}{ Outcome } & \multicolumn{2}{|c|}{ Findings at Necropsy } & \multirow{2}{*}{ Comment } \\
\hline & & & & & $\begin{array}{l}\text { Immediate Cause } \\
\text { of Death }\end{array}$ & State of Lungs & \\
\hline $7 \cdot 03$ & $7 \cdot 12$ & - & - & $\begin{array}{l}\text { Death } \\
46 \mathrm{hr} .\end{array}$ & IVH & $\begin{array}{l}\text { Normal; surfactant } \\
\text { present }\end{array}$ & \\
\hline 6.90 & $7 \cdot 04$ & 95 & 64 & $\begin{array}{l}\text { Death } \\
6 \mathrm{hr} \text {. }\end{array}$ & RDS & HAD & $\begin{array}{l}\text { Repeated apnoeic attacks } \\
\text { IPPR from } 4 \mathrm{hr} \text {. }\end{array}$ \\
\hline $7 \cdot 03$ & $7 \cdot 13$ & 30 & 30 & $\begin{array}{l}\text { Death } \\
41 \mathrm{hr} .\end{array}$ & IVH & $\begin{array}{l}\text { Normal; surfactant } \\
\text { present }\end{array}$ & \\
\hline $\begin{array}{l}7 \cdot 00 \\
7 \cdot 17 \\
6 \cdot 88\end{array}$ & $\begin{array}{l}7 \cdot 09 \\
7 \cdot 21 \\
6 \cdot 92\end{array}$ & $\begin{array}{r}105 \\
54 \\
43\end{array}$ & $\begin{array}{l}73 \\
64 \\
39\end{array}$ & $\begin{array}{c}\text { Survived } \\
\text { Survived } \\
\text { Death } \\
18 \mathrm{hr} .\end{array}$ & $\mathrm{IVH}$ & & $\begin{array}{l}\text { Repeated apnoeic attacks } \\
\text { Good response to } 2 \text { nd } \\
\text { dose THAM; repeated } \\
\text { apnoeic attacks }\end{array}$ \\
\hline $7 \cdot 04$ & $7 \cdot 29$ & 42 & 32 & $\begin{array}{l}\text { Death } \\
19 \mathrm{hr} .\end{array}$ & IVH & Small pneumothorax; & Repeated apnoeic attacks \\
\hline $6 \cdot 83$ & $7 \cdot 02$ & 100 & 66 & $\begin{array}{l}\text { Death } \\
74 \mathrm{hr} \text {. }\end{array}$ & RDS & $\begin{array}{l}\text { HMD; no } \\
\text { surfactant }\end{array}$ & IPPR from onset \\
\hline $7 \cdot 21$ & $7 \cdot 25$ & 29 & 35 & $\begin{array}{l}\text { Death } \\
46 \mathrm{hr} .\end{array}$ & RDS & Pneumonia; HMD & \\
\hline $6 \cdot 94$ & $6 \cdot 95$ & 65 & 51 & Death & RDS & $\begin{array}{l}\text { HMD; no } \\
\text { surfactant }\end{array}$ & \\
\hline $\begin{array}{l}7 \cdot 01 \\
6 \cdot 99\end{array}$ & $\begin{array}{l}7 \cdot 12 \\
7 \cdot 00 \\
7 \cdot 13\end{array}$ & $\begin{array}{r}60 \\
160 \\
127\end{array}$ & $\begin{array}{r}39 \\
127 \\
72\end{array}$ & $\begin{array}{l}\text { Survived } \\
\text { Survived }\end{array}$ & & & $\begin{array}{l}\text { Good response to } 2 \text { nd } \\
\text { dose of THAM }\end{array}$ \\
\hline $7 \cdot 04$ & $7 \cdot 12$ & 59 & 41 & Death & RDS; aspir. & HMD & $\begin{array}{l}\text { Massive antepartum } \\
\text { haemorrhage }\end{array}$ \\
\hline $6 \cdot 82$ & $\begin{array}{r}6 \cdot 97 \\
-\end{array}$ & 120 & 68 & $\begin{array}{l}\text { Death } \\
9 \text { hr. } \\
\text { Survived }\end{array}$ & RDS & HMD & $\begin{array}{l}\text { Hypothermia; IPPR } \\
\text { from } 4 \ddagger \mathrm{hr} \text {. }\end{array}$ \\
\hline $\begin{array}{l}7 \cdot 29 \\
6 \cdot 93\end{array}$ & $\overline{7 \cdot 04}$ & $\begin{array}{l}30 \\
65\end{array}$ & $\overline{38}$ & $\begin{array}{l}\text { Survived } \\
\text { Death } \\
14 \mathrm{hr} \text {. }\end{array}$ & $\begin{array}{l}\text { Subdural } \\
\text { haemorrhage }\end{array}$ & HMD & Repeated apnoeic attacks \\
\hline $7 \cdot 20$ & $7 \cdot 19$ & 38 & 31 & $\begin{array}{l}\text { Death } \\
66 \mathrm{hr} .\end{array}$ & IVH & $\begin{array}{l}\text { Bronchopneumonia } \\
\text { HMD }\end{array}$ & Placenta praevia APH \\
\hline $7 \cdot 06$ & $7 \cdot 09$ & 38 & 26 & $\begin{array}{l}\text { Death } \\
23 \mathrm{hr} \text {. }\end{array}$ & RDS & $\begin{array}{l}\text { Atelectasis; pulm. } \\
\text { haem. }\end{array}$ & Repeated apnoeic attaç \\
\hline $\begin{array}{l}6 \cdot 89 \\
7 \cdot 06\end{array}$ & $\begin{array}{l}7 \cdot 06 \\
7 \cdot 10\end{array}$ & $\begin{array}{l}87 \\
50 \\
62\end{array}$ & $\begin{array}{l}58 \\
62 \ddagger \\
37\end{array}$ & $\begin{array}{l}\text { Survived } \\
\text { Survived }\end{array}$ & & & 高. \\
\hline $\begin{array}{l}7 \cdot 14 \\
7 \cdot 12\end{array}$ & $\begin{array}{l}7 \cdot 32 \\
7 \cdot 17\end{array}$ & $\begin{array}{l}69 \\
52\end{array}$ & $\begin{array}{l}38 \\
38\end{array}$ & $\begin{array}{l}\text { Survived } \\
\text { Death } \\
41 \mathrm{hr} \text {. }\end{array}$ & $\begin{array}{l}\text { Tension } \\
\text { pneumothorax }\end{array}$ & HMD & \\
\hline $7 \cdot 18$ & 一 & 25 & - & $\begin{array}{l}\text { Death } \\
69 \mathrm{hr} \text {. }\end{array}$ & Pneumonia & Pulm. haem.; HMD & $\begin{array}{l}\text { Severe intrapartum } \\
\text { asphyxia }\end{array}$ \\
\hline $\begin{array}{l}7 \cdot 26 \\
7 \cdot 33\end{array}$ & $\stackrel{7 \cdot 26}{-}$ & $\begin{array}{l}52 \\
24\end{array}$ & $\underline{45}$ & $\begin{array}{l}\text { Survived } \\
\text { Survived }\end{array}$ & & & $\begin{array}{l}\text { Intrapartum asphyxia } \\
\text { Intrapartum asphyxia }\end{array}$ \\
\hline
\end{tabular}

clinical improvement corresponded with a sudden rise in $\mathrm{P}_{\mathrm{a}} \mathrm{O}$., which was sustained, and the infant subsequently recovered.

Case 44. This infant was a vertex delivery following a spontaneous premature labour. At 1 minute he was gasping with a heart rate of $180 / \mathrm{min}$. He subsequently deteriorated and required intubation but breathed spontaneously at 5 minutes. At 2 hours he had marked costal recession, grunting respiration, and a respiratory rate of $80 / \mathrm{min}$. Air entry was poor. Chest $x$-ray film was compatible with RDS. Fig. 4 shows the blood gas and $p \mathrm{H}$ values before and after THAM. There was a marked improvement during the time THAM was being given. The costal recession became less: the grunting respirations eased; and the infant showed more activity. At this time the right radial artery was catheterized and thereafter simultaneous arterial samples were taken from the radial artery and the lower aorta (i.e. above and below the ductus). It can be seen that $\mathrm{P}_{\mathrm{a}} \mathrm{O}$., values from each site were identical. A single dose of $5 \mathrm{mEq}$ sodium bicarbonate was given at the age of $6 \frac{1}{2}$ hours as the $p \mathrm{H}$ had not risen as expected. This caused a rise in $p \mathrm{H}$ but? a fall in $\mathrm{P}_{\mathrm{a}} \mathrm{O}_{2 .}$. The infant made an uneventful recovery.

Fatal cases of 'bad prognosis' group. The associ-ồ ated illness, the immediate cause of death and relevant post-mortem lung findings are shown in Table II. Fig. 2 shows the $\mathrm{P}_{\mathrm{a}} \mathrm{O}_{2}$ values (derived? from isopleths) at a $\mathrm{P}_{\mathrm{A}} \mathrm{O}_{2}$ of $660 \mathrm{~mm}$. $\mathrm{Hg}$ before and after THAM.

Three of these infants (Nos. 34, 36, and 39) hadN substantial and sustained increases in the $\mathrm{P}_{\mathrm{a}} \mathrm{O}_{2} \stackrel{\mathrm{C}}{\mathrm{N}}$ following THAM. They were recovering from RDS and had normal gas tensions, when they suddenly deteriorated and died at the age of 46,41 , and 18 hours, respectively. It will be noted that $\stackrel{\oplus}{+}$ Nos. 34 and 36 had stable lungs at necropsy.

Infants Nos. 35, 38, 39, 40, 49, and 51 had repeated apnoeic attacks requiring intubation and 


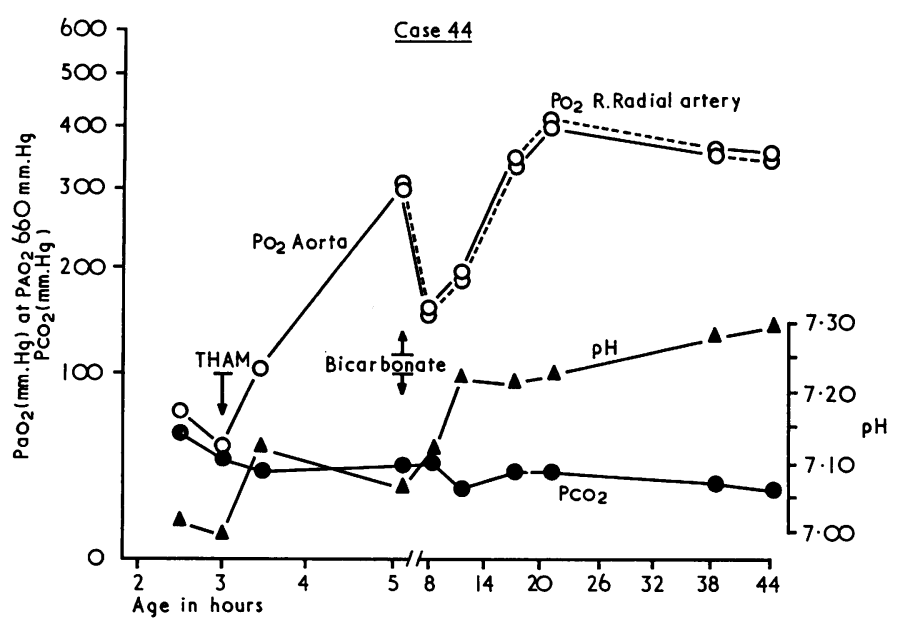

FIg. 4.-Case 44. Arterial oxygen tension, $\mathrm{pH}$, and $\mathrm{Pco}_{2}$ before and after THAM (see text).

IPPR at times during their illness. Only one (No. 38) of this group survived: in the remainder there was little response to THAM and, where a rise in the $\mathrm{P}_{\mathrm{a}} \mathrm{O}_{2}$ was obtained, it was not sustained.

It can be seen that of these 15 infants only 7 died from RDS alone. Among these 7 infants, Cases 42 and 55 showed satisfactory $\mathrm{P}_{\mathrm{a}} \mathrm{O}_{2}$ values initially but subsequently deteriorated, while infant No. 41 was treated late in the disease, requiring IPPR from the outset. The $\mathrm{P}_{\mathrm{a}} \mathrm{O}_{2}$ did not rise with THAM in these cases.

The $p \mathrm{H}$ which was below $7 \cdot 20$ at the outset in all cases rose following THAM in all but one; this rise, however, was not sustained.

The $\mathrm{P}_{\mathrm{a}} \mathrm{CO}_{2}$ was raised initially in all cases except one. Again there was a consistent fall following THAM, but subsequently the levels once again rose. Infant No. 41 had the right radial artery catheterized and simultaneous measurements of $\mathrm{P}_{\mathrm{a}} \mathrm{O}_{2}$ were made from this site and from the lower aorta. The values obtained were identical in each instance, indicating there was no net right-to-left shunt through the ductus. Cases 36 and 43 illustrate these points.

Case 36. This infant was born following a spontaneous premature labour by vertex delivery. He was apnoeic at 1 minute of age, heart rate $40 / \mathrm{min}$., cyanosed, and limp. He was intubated and given IPPR. The colour improved and spontaneous respiration started at 4 minutes, but he remained unresponsive for 15 minutes. $\mathrm{He}$ developed respiratory distress and at the age of 1 hour the $\mathrm{P}_{\mathrm{a}} \mathrm{O}_{2}$ was $51 \mathrm{~mm}$. $\mathrm{Hg}$, and the $\mathrm{pH} 7.03$ (Fig. 5). Ten minutes after THAM the $\mathrm{P}_{\mathrm{a}} \mathrm{O}_{2}$ rose to $190 \mathrm{~mm}$. $\mathrm{Hg}$ and the $p \mathrm{H}$ to $7 \cdot 13$; the $\mathrm{P}_{\mathrm{a}} \mathrm{CO}_{2}$ remained at $30 \mathrm{~mm}$. $\mathrm{Hg}$. His clinical condition also improved in that grunting became less and costal recession eased. The gas tension and $p \mathrm{H}$ remained satisfactory until the age of 37 hours when he suddenly became pale and limp. Shortly afterwards he had the first of three apnoeic attacks and despite IPPR he died at the age $\mathbf{4 1}$ hours.

Necropsy showed a massive intraventricular haemorrhage and well-expanded lungs. Pressure-volume curves were normal and surfactant was detected in the lungs.

Case 43. This infant was born following a spontaneous premature labour at 33 weeks by a vertex delivery. At 1 minute the infant was gasping, heart rate $110 / \mathrm{min}$., and was blue. The colour improved with face-mask oxygen, but he then developed respiratory distress. Fig. 6 shows the blood gas tension and $p H$. At 3 hours of age the $\mathrm{P}_{\mathrm{a}} \mathrm{O}_{2}$ was $27 \mathrm{~mm}$. $\mathrm{Hg}, p \mathrm{H} \mathrm{6.94}$, and $\mathrm{P}_{\mathrm{a}} \mathrm{CO}_{2}$ $65 \mathrm{~mm}$. Hg. Following THAM the $\mathrm{P}_{\mathrm{a}} \mathrm{O}_{2}$ rose slightly, the $\mathrm{P}_{\mathrm{a}} \mathrm{CO}_{2}$ fell, and the $\mathrm{pH}$ remained the same. Subsequently doses of THAM produced little response and terminally the $\mathrm{P}_{\mathrm{a}} \mathrm{CO}_{2}$ rose and $p \mathrm{H}$ fell. $\quad\left(\mathrm{P}_{\mathrm{a}} \mathrm{O}_{2}\right.$ measurements were not obtained in the latter stages due to a fault in the apparatus.)

Necropsy showed the lungs to be collapsed; histology revealed hyaline membrane; and no surfactant was detected after 24 hours cycling. Owing to a technical breakdown this infant was not treated adequately in the early stages of the disease.

Effect of THAM on arterial blood pressure. The arterial blood pressure was recorded directly by a pressure transducer in 5 infants while THAM was being administered via the umbilical vein. There was no change in the blood pressure during this time and for periods of up to 20 minutes afterwards. 


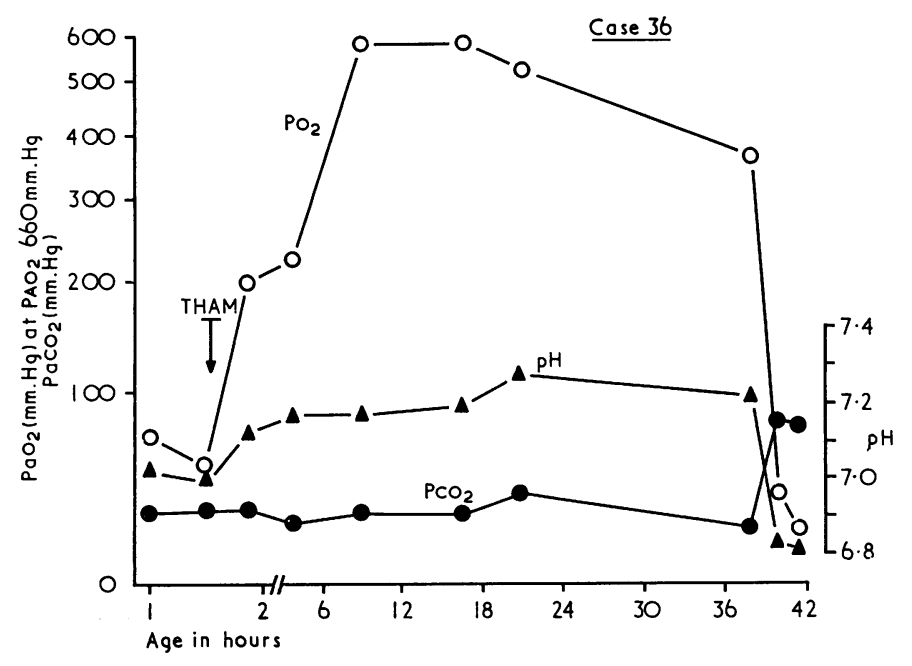

Fig. 5.-Case 36. Arterial oxygen tension, $\mathrm{pH}$, and $\mathrm{Pco}_{2}$ before and after giving THAM (see text).

Side effects. THAM has been shown to cause hypoglycaemia and hyperkalaemia (Bennett and Tarail, 1961) in animal experiments but no such effects were seen in this series of human infants. Respiratory depression (Nahas, Fink, Ploski, and Teneick, 1963) was observed on occasions, but only in the terminal stages of the illness and never with the initial dose. On one occasion a fall rather than a rise in $\mathrm{P}_{\mathrm{a}} \mathrm{O}_{2}$ was seen after an injection of THAM which was given into the umbilical artery. This was not associated with a fall in $\mathrm{P}_{\mathrm{a}} \mathrm{CO}_{2}$ or rise in $p \mathrm{H}$. It will be noted that this patient had a tension pneumothorax. We do not recommend the use of THAM in cases of predominantly metabolic acidaemia when the $\mathrm{P}_{\mathrm{a}} \mathrm{CO}_{2}$ level is within the normal range for newborn infants, since in these circumstances it may cause respiratory depression.
Management. The use of THAM in respiratory distress necessitates the presence of indwelling umbilical arterial and venous catheters over the course of the illness both for injection (which causes tissue necrosis when given through smaller vessels) and for monitoring blood gas tensions and $p \mathrm{H}$. A measure of the dramatic effect of treatment in some cases is the need to watch for excessively high oxygen tensions after THAM in treated infants nursed in high ambient oxygen concentrations. The presence of indwelling catheters makes it imperative to avoid umbilical sepsis, and this can be achieved by spraying the cord stump at birth and daily thereafter with 'polybactrin' and by painting it with iodine before manipulation. The use of heparin to keep the catheters open involves partial heparinization of the infant, and this may need to be

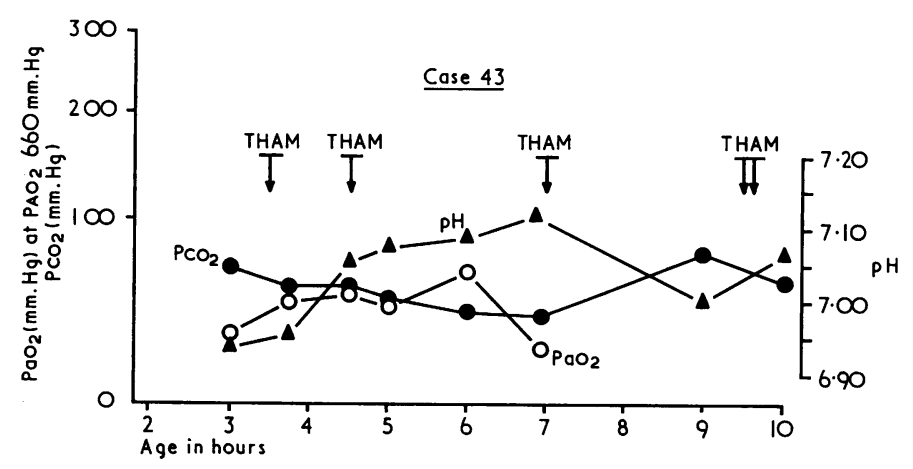

FIG. 6.-Case 43. Arterial oxygen tension, $\mathrm{pH}$, and $\mathrm{Pco}_{2}$ before and after giving THAM (see text). 
countered with appropriate quantities of protamine when the infant is tiny and frequent sampling is needed.

In none of these cases was there any clinical or post-mortem evidence of arterial thrombosis. In 3 (very small) babies one leg became pale and pulseless, but the circulation was restored immediately on removal of the catheter.

Finally, careful precautions have to be taken against bleeding from the cord stump when the catheters are removed, and, indeed, from the catheters themselves. In cases in which very frequent sampling is in the infant's interest, we do not hesitate to replace the blood that is removed by a small transfusion, if this exceeds $10 \%$ of the calculated blood volume.

\section{Discussion}

The results presented re-emphasize the need for a clear distinction between good prognosis and bad prognosis RDS in the evaluation of treatment, the former having a good prognosis as regards respiratory sufficiency even without specific treatment for acidaemia, the latter doing badly if such therapy is withheld. Initial $\mathrm{P}_{\mathrm{a}} \mathrm{O}_{2}$ levels in $100 \%$ ambient oxygen concentrations have been shown by a number of workers (Boston et al., 1966; Moss et al., $1965)$ to be a more reliable guide to prognosis than changes in $p \mathrm{H}$, standard bicarbonate, or $\mathrm{P}_{\mathrm{a}} \mathrm{CO}_{2}$ levels; and on this basis it is possible to single out a group of badly affected infants whose mortality conventionally treated is of the order of $80 \%$. Improvement in the outlook of this category is in our opinion likely to be a better guide to the efficiency of treatment than comparison of death rates in consecutive series, or even in alternate but unselected cases, in a disease where the prognosis is affected by so many variables. For instance, in our experience two-thirds of infants who die of massive intraventricular haemorrhage (IVH) have no clinical or pathological evidence of RDS, and in one-third of all cases dying of RDS there is an associated IVH, though in some of these the haemorrhage occurred when the infant no longer showed signs of respiratory failure. The undoubted association of RDS and IVH may be coincidental on the basis of low gestational age.

Treatment of the secondary metabolic effects of respiratory failure in RDS with mixtures of water, sodium, glucose, and bicarbonate, has been in vogue since its introduction by Usher (1959). From some centres (Hutchison et al., 1964) it is claimed that the prognosis can be greatly improved thereby, though Usher himself has pointed out (1963) that glucose/ bicarbonate therapy does not seem to improve the prognosis in babies of under $1500 \mathrm{~g}$. birthweight, a category that includes many of the severe cases; and the results of a reasonably well-controlled trial in a large series of cases in Singapore have demonstrated no significant advantages to the treated infants (Teck, 1965).

In our view, death in RDS is primarily due to hypoxia and therefore, in a disease that lasts for upwards of $\mathbf{4 8}$ hours, any attempt to neutralize the acidaemia resulting from inadequate pulmonary $\mathrm{CO}_{2}$ elimination by infusion of buffer or alkali is unlikely to succeed in just those cases where respiratory failure is of a degree to threaten life. The demonstration that in certain circumstances the administration of alkali actually appears to improve oxygenation, as well as correcting $p \mathrm{H}$, etc., and that this improvement may be sustained, is therefore of considerable importance both in theory and practice. That it is seen alike in ultimately fatal cases, in babies on IPPR, and in bad risk infants who recover, makes it unlikely that the effect is due to spontaneous improvement, to changes in respiration, or to random fluctuation in $\mathrm{P}_{\mathrm{a}} \mathrm{O}_{2}$. As suggested by Gupta (1965) and independently by Chu et al. (1965), it also implies that part of the respiratory failure in RDS is the result of the inadequate pulmonary perfusion; indeed, the very rapid response to treatment suggests that this may be the primary cause of the disease and that other changes, such as loss of surfactant, demonstrable at necropsy, may be in some measure secondary. Inadequate pulmonary perfusion is presumably the result of either a low cardiac output or of the shunting of blood past functional lung tissue, i.e. through the foramen ovale, through the ductus arteriosus, or through nonventilated lung. This involves an alteration in normal pressure relationship (Rudolph, Drorbaugh, Auld, Rudolph, Nadas, Smith, and Hubbell, 1961; Moss, Emmanouilides, and Duffie, 1963) such that (1) in the case of the foramen ovale, right atrial pressure must exceed left atrial pressure, (2) in the case of the ductus, pulmonary arterial must exceed systemic arterial pressure, and (3) where there is perfusion of unventilated lung, the vascular resistance in the unventilated segments must not increase. We have not measured cardiac output, nor pressure in the atria, ventricles, or great vessels, but in 5 cases in which the arterial pressure was measured before and after THAM, no change was noted. In 4 further cases in which $\mathrm{P}_{\mathrm{a}} \mathrm{O}_{2}$ levels were measured simultaneously in the aorta (via the umbilical artery) and in the right radial artery, there was no difference between $\mathrm{P}_{\mathrm{a}} \mathrm{O}_{2}$ levels above and below the opening of the ductus arteriosus into the aorta. It is, therefore, 
unlikely that changes in cardiac output or in ductal shunting were responsible for the $\mathrm{P}_{\mathrm{a}} \mathrm{O}_{2}$ changes observed following THAM in these cases. Since the closure of the foramen ovale is dependent on a change in atrial pressure relationships caused by the increase in pulmonary perfusion that takes place at birth, and since this increase in pulmonary perfusion probably results from a fall in pulmonary vascular resistance, it seems likely that in RDS there may be a major shunting through the foramen ovale and that this is in part due to a rise in pulmonary vascular resistance producing a fall in pulmonary blood flow. Pulmonary vascular resistance is known to be dependent on pulmonary gas tensions and pulmonary distension (Cassin et al., 1964; Rokseth, 1966), both of which are likely to be altered in an adverse way in the course of RDS, and it, therefore, seems possible that the timely administration of alkali may, by lowering pulmonary vascular resistance, promote adequate pulmonary perfusion, reduce shunting, improve blood and alveolar gas tensions, and prevent irreversible pulmonary damage. It appears likely that the changes in $\mathrm{P}_{\mathrm{a}} \mathrm{O}_{2}$ described are due to a direct effect of THAM in the lung or on the heart rather than to changes in total body acid-base balance, the doses used probably being too small to achieve the results observed except through a concomitant improvement in respiratory function. It may be that in some cases lack of response to alkali was due to a failure of the drug to reach the lung or heart, either because of extreme shunting, lodgement of the venous catheter in the liver, or injection into the umbilical artery instead of vein, whereas in others it was because the drug was given too late when irreversible pulmonary damage had occurred. This effect could be on the pulmonary arteries (pulmonary artery pressure is known to be high except in the terminal stages of the illness (Rudolph et al., 1961; Moss et al., 1965)), but since the apparent pulmonary hypoperfusion is accompanied by congestion of the lung at necropsy, an effect on the pulmonary veins seems more likely. A. J. Hauck (1963, personal communication) has in fact observed a raised pulmonary venous pressure in RDS in the presence of a normal left atrial pressure. That hypoperfusion is the initiating disturbance would, for instance, explain the normal quantities of surfactant found at necropsy in the two cases described in this report, which recovered from severe RDS and subsequently died with IVH after a period when there appeared to be no clinical signs of respiratory embarrassment. The evidence herein adduced, and the argument based thereon, suggests that RDS in its early stages may be aborted rather than ameliorated by the administration of THAM, and that this effect is more likely to be a primary one on the walls of the pulmonary vessels than secondary to changes in total body acid base balance. Direct measurements of the quantities involved (oxygen consumption, pulmonary arterial and atrial pressures), and the calculation of pulmonary blood flow before and after treatment, would go far to disprove or substantiate this hypothesis.

\section{Summary}

Babies with respiratory distress syndrome can be divided into two groups with a good and bad prognosis on the basis of an initial arterial oxygen tension measurement taken when breathing $100 \%$ oxygen, providing a measure of the extent of $\mathrm{V}-\mathrm{A}$ shunting. Following intravenous THAM given early in the course of the illness, there is a considerable and often sustained rise in arterial oxygen tension in the bad prognosis group which can best be accounted for by a diminution in such shunting. The alteration in calculated shunt induced by THAM injection suggests that reversible hypoperfusion is a factor in the aetiology of the pulmonary changes seen in the respiratory distress syndrome.

The authors wish to acknowledge the help of Mrs. Lee, departmental secretary, Mr. J. F. Stevens, senior technician, colleagues at the Royal Postgraduate Medical School, and Professor J. P. M. Tizard in the preparation of this paper. The work reported was stimulated by observations on the effect of THAM in respiratory distress made in the department of Paediatrics, University of Groningen (Professor J. Jonxis, Dr. H. Visser, and Dr. J. Troelstra). Dr. Colin Normand of University College Hospital kindly carried out the determinations of surface tension-reducing activity and Dr. J. S. Wigglesworth the pressure volume curves. The laboratory work was carried out in the Sir William Coxen Laboratories of the Nuffield Neonatal Research Unit using instruments paid for by the Variety Club of Great Britain.

\section{REFERENCES}

Astrup, P. (1956). A simple electrometric technique for the determination of carbon dioxide tension in blood and plasma, total content of carbon dioxide in plasma and bicarbonate content in 'separated' plasma at a fixed carbon dioxide tension (40 mm. Hg). Scand. F. clin. Lab. Invest., 8, 33.

Bennett, T. E., and Tarail, R. (1961). The hypoglycemic activity of 2-amino-2 hydroxymethyl-1, 3-propanediol. Ann! N.Y. Acad. Sci., 92, 651.

Boston, R. W., Geller, F., and Smith, C. A. (1966). Arterial blood gas tensions and acid-base balance in the management of the respiratory distress syndrome. F. Pediat., 68, 74.

Bradley, A. F., Stupfel, M., and Severinghaus, J. W. (1956). Effect of temperature on $\mathrm{PCO}_{2}$ and $\mathrm{PO}_{2}$ of blood in vitro. f. appl. Physiol., 9, 201.

Cassin, S., Dawes, G. S., Mott, J. C., Ross, B. B., and Strang, L. B. (1964). The vascular resistance of the foetal and newly ventilated lung of the lamb. $\mathcal{F}$. Physiol. (Lond.), 171, 61 .

Chu, J., Clements, J. A., Cotton, E., Klaus, M. H., Sweet, A. Y., Thomas, M. A., and Tooley, W. H. (1965). The pulmonary hypoperfusion syndrome. Pediatrics, $35,733$. 
Gupta, J. M. (1965). The effect of THAM on the oxygen tension of arterial blood in neonatal respiratory-distress syndrome. Lancet, 1, 734.

- (1966). Studies in blood gas tension and acid base balance in normal and sick newborn infants. M.D. Thesis, University of Singapore.

Hedley-Whyte, J., and Laver, M. B. (1964). $\mathrm{O}_{2}$ solubility and temperature correction factors for $\mathrm{Po}_{2}$. $\mathcal{~}$. appl. Physiol., 19, 901.

Holmdahl, M. H., Nahas, G. G., Hassam, D., and Verosky, M. (1961). Acid-base changes in the cerebrospinal fluid following rapid changes in the bicarbonate/carbonic acid ratio in the blood. Ann. N.Y. Acad. Sci., 92, 520.

Hutchison, J. H., Kerr, M. M., Douglas, T. A., Inall, J. A., and Crosbie, J. C. (1964). A therapeutic approach in 100 cases of the respiratory distress syndrome of the newborn infant. Pediatrics, 33, 956.

Moss, A. J., Emmanouilides, G., and Duffie, E. R., Jr. (1963). Closure of the ductus arteriosus in the newborn (Abstract). F. Pediat., 63, 709.

- - Retorri, O., Higashino, S. M., and Adams, F. H. (1965), Postnatal circulatory and metabolic adjustments in normal and distressed premature infants. Biol. Neonat. (Basel), 8, 177.

Nahas, G. G. (1959). Use of an organic carbon dioxide buffer in vivo. Science, 129, 782.

- Fink, B. R., Ploski, W. S., and Teneick, R. E. (1963). The depressant effects of tris (hydroxymethyl)-aminomethane and of mannitol on respiration. Ann. N.Y. Acad. Sci., 109, 783.

Nelson, N. M., and Reynolds, E. O. R. (1964). Hyperbaric oxygen in patients with venoarterial shunts. Theoretical implications. New Engl. 7. Med., 271, 497.

Peters, J. P. (1923). Studies of the carbon dioxide absorption curve of human blood. III. A further discussion of the form of the absorption curve plotted logarithmically, with a convenient type of interpolation chart. 7 . biol. Chem., 56, 745.

Rokseth, R. (1966). The effect of altered blood $\mathrm{CO}_{2}$ tension and $\mathrm{pH}$ on the human pulmonary circulation. Scand. F. clin. Lab. Invest., 18, Suppl. 90.

Rosenthal, T. B. (1948). The effect of temperature on the $p H$ of blood and plasma in vitro. F. biol. Chem., 173, 25.

Rudolph, A. M., Drorbaugh, J. E., Auld, P. A. M., Rudolph, A. J., Nadas, A. S., Smith, C. A., and Hubbell, J. P. (1961). Studies on the circulation in the neonatal period. The circulation in the respiratory distress syndrome. Pediatrics, 27, 551.

Scopes, J. W., and Ahmed, I. (1966). Range of critical temperatures in sick and premature newborn babies. Arch. Dis. Childh., 41, 417.

Stevens, J. F., and Lanning, K. (1964). Micro $\mathrm{PCO}_{2}$ equilibration unit. Lancet, 2, 447.

Teck, T. W. T. (1965). Respiratory distress syndrome of the newborn in Kandang Kerbau Hospital. $\mathcal{f}$. Singapore paediat. Soc., 7, 44.

Tizard, J. P. M. (1964). Indications for oxygen therapy in the newborn. Pediatrics, 34, 771.

Usher, R. (1959). The respiratory distress syndrome of prematurity. I. Changes in potassium in the serum and the electrocardiogram and effects of therapy. ibid., 24, 562 .

- (1963). Reduction of mortality from respiratory distress syndrome of prematurity with early administration of intravenous glucose and sodium bicarbonate. ibid., 32, 966.

\section{Appendix}

\section{Sources of Errors Due to Assumptions Made in Calculating Shunt}

End pulmonary capillary oxygen content $\left(\mathrm{CCO}_{2}\right)$ has been derived from alveolar oxygen tension $\left(\mathrm{P}_{\mathbf{A}} \mathrm{O}_{2}\right)$ using the alveolar air equation. While entirely valid for subjects who are breathing normally, the assumption does not hold when there is any degree of respiratory depression, for this causes a fall in $\mathrm{P}_{\mathrm{A}} \mathrm{O}_{2}$, as a result of which the calculated value for $\mathrm{CCO}_{2}$ will be higher than the actual one; so giving a falsely high shunt value. However, if the alveolar $\mathrm{PO}_{2}$ is high, the fall in $\mathrm{CCO}_{2}$ due to hypoventilation will be very small, and greater accuracy can therefore be expected in calculating the right-to-left shunt if the subject breathes a high concentration of oxygen rather than air (Perkins, Adams, Flores, Harper, and Landahl, 1958).

Large right-to-left shunts (over $70 \%$ ) cause arterial $\mathrm{PCO}_{2}$ appreciably to exceed alveolar values (Strang and MacLeish, 1961), and this will give a falsely low value for alveolar $\mathrm{Po}_{2}$ by the alveolar air equation. As the error is small no correction for it has been made.

For the calculation of alveolar $\mathrm{PO}_{2}$ the respiratory quotient has been assumed to be $0 \cdot 8$. In the newborn infant $R Q$ varies from $0 \cdot 7$ to $1 \cdot 0$ (Cross, Tizard, and Trythall, 1957) and this could result in a maximum error of $40 \mathrm{~mm}$. $\mathrm{Hg}$ in the calculated $\mathrm{P}_{\mathrm{A}} \mathrm{O}_{2}$ in a severely ill infant. Such infants, however, will be breathing very high concentrations of oxygen and as such the error in the calculated shunt will be small.

As explained in the text, mixed venous samples are difficult to obtain in newborn babies. Strang and MacLeish (1961) observed that the arteriovenous oxygen differences in all their cases were between 2 and $6 \mathrm{ml} . / 100 \mathrm{ml}$., and they showed that the calculated shunt value at 4 did not differ from those at 2 and $6 \mathrm{ml} . / 100 \mathrm{ml}$. by more than $12 \%$; hence, with an assumption of an arteriovenous difference of $4 \mathrm{ml} . / 100 \mathrm{ml}$. an error of $\pm 12 \%$ may occur.

Oxygen capacity has been assumed to be $20 \mathrm{ml} . / 100 \mathrm{ml}$., which is equivalent to $15 \cdot 8 \mathrm{~g}$. $\mathrm{Hb} / 100 \mathrm{ml}$. This is, of course, not correct for all infants since their $\mathrm{Hb}$ concentrations may differ. Moreover, because of the changes in haematocrit that occur in the first few days of life (Gairdner, Marks, Roscoe, and Brettell, 1958) the value in a particular infant will also vary. To determine the magnitude of the error, shunts were calculated by assuming oxygen capacities of $18 \cdot 2$ and $23.4 \mathrm{ml} . / 100 \mathrm{ml}$. (i.e. $\mathrm{Hb}$ concentrations of 14 and $18 \mathrm{~g} . / 100 \mathrm{ml}$.). The maximum difference was $\pm 10 \%$ from those calculated by assuming a value of $20 \mathrm{ml} . / 100 \mathrm{ml}$.

A further uncertainty is introduced by the fact that the proportion of foetal $\mathrm{Hb}$ may vary in the infants studied; whereas the standard oxygen dissociation curve for foetal $\mathrm{Hb}$ at $37^{\circ} \mathrm{C}$. at $\mathrm{pH} 7 \cdot 40$ was used to determine the oxygen content in all cases.

Another possible source of error is that the results are expressed as percentage of cardiac output, which of course may vary from time to time in a particular infant. No correction has been applied to the oxygen dissociation curve for differences in temperature and $\mathrm{pH}$, as recommended by Bradley, Stupfel, and Severinghaus (1956), since the error introduced by this omission is insignificant in relation to other possible errors as a result of the assumptions made.

Because of all these possible sources of error the changes in shunting demonstrated must be considered as only semi-quantitative, but this does not affect the argument of the paper, which remains valid.

\section{REFERENCES}

Bradley, A. F., Stupfel, M., and Severinghaus, J. W. (1956). The effect of temperature on $\mathrm{PCO}_{2}$ and $\mathrm{PO}_{2}$ of blood in vitro. $\mathcal{F}$. appl. Physiol., 9, 201. 
Cross, K. W., Tizard, J. P. M., and Trythall, D. A. H. (1957). The gaseous metabolism of the newborn infant. Acta paediat. (Uppsala), 46, 265.

Gairdner, D., Marks, J., Roscoe, J. D., and Brettell, R. O. (1958). The fluid shift from the vascular compartment immediately after birth. Arch. Dis. Childh., 33, 489.
Perkins, J. F., Jr., Adams, W. E., Flores, A., Harper, P. V., and Landahl, H. D. (1958). Arterial $\mathrm{O}_{2}$ saturation vs. alveolar $\mathrm{O}_{2}$ tension in anatomical venous-arterial shunting. $\mathcal{f}$. appl. Physiol., 12, 71.

Strang, L. B., and MacLeish, M. H. (1961). Ventilatory failure and right-to-left shunt in newborn infants with respiratory distress. Pediatrics, 28, 17.

The following articles will appear in future issues of this Journal:

Adrenal Cortex in Marasmic Children. By Samir S. Najjar and John G. Bitar.

Effects of Amino Acid Loads on a Healthy Infant with the Biochemical Features of Hartnup Disease. By J. W. T. Seakins and R. S. Ersser.

Immunochemical Estimation of Some Proteins in Nigerian Paired Maternal Foetal Blood. By H. McFarlane and I. O. K. Udeozo.

Treatment of Classical Phenylketonuria. By M. S. McBean and J. B. P. Stephenson.

Duodenal Ulcer in Childhood. A Study of Predisposing Factors. By B. F. Habbick, A. G. Melrose, and J. C. Grant.

Milk Intolerance in Infancy. By Hilton Silver and D. M. Douglas.

Classification of Protein-calorie Undernutrition in Children. By K. L. Mukherjee.

Comparison of Methods for Evaluating Surface Properties of Lung. By Gillian Gandy, J. G. Bradbrooke, B. T. Naidoo, and Douglas Gairdner.

Transient Respiratory Distress Syndrome in the Newborn. By John J. Downes, Subhash Arya, Grant Morrow, III, and Thomas R. Boggs, Jr.

Intracranial Haemorrhage Associated with Hyaline Membrane Disease. By V. C. Harrison, H. de V. Heese, and M. Klein.

Incidence and Treatment of Infantile Gastro-enteritis in General Practice. By David Wheatley.

Myoclonic Epilepsy in Childhood. By J. R. Harper.

Angiokeratoma Corporis Diffusum. Some Clinical Aspects. By A. W. Johnston, S. D. V. Weller, and B. J. Warland.

Emetine Hydrochloride and Dehydroemetine Combined with Chloroquine in the Treatment of Children with Amoebic Liver Abscess. By J. N. Scragg and S. J. Powell.

Serum-Insulin Changes Following Administration of L-leucine to Children. By D. B. Grant.

Lincomycin in the Treatment of Penicillin-resistant Staphylococcal Infections in Children. By J. F. R. Bentley and D. Pollock.

Hereditary Pituitary Dwarfism with Spontaneous Puberty. By M. Seip, C. B. van der Hagen, and O. Trygstad. Histidinaemia: A Child and his Family. By A. R. R. Cain and J. B. Holton. 